\title{
Influência do investimento estrangeiro direto na economia brasileira: uma análise por setores da economia*
}

\author{
Izabela Ferreira Serra ${ }^{11}$
}

\section{Resumo}

O presente trabalho tem por objetivo analisar a influência da entrada de Investimento Estrangeiro Direto (IED) nos diversos setores da economia brasileira. Portanto, foram observados os fluxos mundiais de IED, a legislação brasileira que regulamenta a entrada de IED no país, bem como o contexto histórico que influenciou os influxos de IED no Brasil. Realizou-se, então, uma análise da entrada de IED e do crescimento dos setores da economia brasileira no período de 2000 a 2008, observando se há relação direta entre eles. Ao final, concluiu-se que os dois fatores analisados estão ligados, porém, o crescimento da economia nacional influencia mais na entrada de IED do que o contrário. Outros fatores que influenciam a entrada de IED e o crescimento interno foram apontados, sugerindo maiores investimentos nacionais como forma de atrair IED a fim de ampliar o comércio internacional e obter mais desenvolvimento tecnológico.

Palavras-chave: Investimento Estrangeiro Direto. Setores da economia. Desenvolvimento. Crescimento.

\section{Introdução}

Investir é aplicar dinheiro em títulos, em imóveis ou em outros meios para obter ganhos econômicos ou financeiros. Porém, o conceito de investimento em macroeconomia nada tem a ver com investimentos financeiros ou compra e venda de ativos, como a privatização. Investimento em macroeconomia é o acréscimo do

* Recebido em 27.10.2009

Aprovado em 13.04.2010

1 Graduada em Relações Internacionais pelo Centro Universitário de Brasília - UniCEUB.

E-mail para contato: izafserra@gmail.com 
estoque físico de capital (formação de capital fixo mais variação de estoque), por meio, por exemplo, da construção de novas fábricas. Os principais motivos para investimento são a acumulação de capital, a administração de recursos e a especulação em busca de melhores resultados financeiros.

O investidor pode ser individual ou coletivo, pessoa física ou jurídica, fundo ou entidade de investimento coletivo. E para ser considerado investimento estrangeiro, basta que este investidor não tenha residência ou sede no país onde investirá.

Os investimentos estrangeiros podem ser diretos ou indiretos (de portfólio). O investimento direto se refere a investimentos que demandam longos prazos e refletem um interesse duradouro por parte do investidor, podendo ser a criação ou aquisição de empresa (ou de parte dela). Já o de portfólio se refere a empréstimos, a ações ou a financiamentos.

A importância dos investimentos diretos na economia de um país é relativa ao montante de dinheiro envolvido nessa operação bem como aos avanços econômicos, sociais e tecnológicos que os estrangeiros levam às diferentes áreas do país receptor.

Sendo assim, o objetivo do presente trabalho é analisar se a relação entre a evolução qualitativa das economias receptoras e os investimentos estrangeiros diretos é verdadeira, tendo como base os investimentos em diversas áreas da economia brasileira; ou seja, este trabalho visa verificar se os investimentos estrangeiros diretos são determinantes para o crescimento interno da economia nacional.

Com esse objetivo foram utilizadas a Teoria Liberal, a Teoria do Desenvolvimento Econômico (SCHUMPETER, 1982), elaborada por Joseph Alois Schumpeter, e a Teoria Dinâmica da Produção (ROSTOW, 1978), elaborada por W. W. Rostow.

\section{Perspectiva Liberal}

A Teoria Liberal é uma das vertentes aceitas para explicar o funcionamento do sistema internacional existente hoje. O que isso significa é que os indivíduos são livres 
e se desenvolvem à medida que trocam informações sobre valores e ideais e têm assim a oportunidade de expandi-los, não lhes sendo imposta nenhuma verdade absoluta. A igualdade também é característica marcante desse pensamento; ela é definida no âmbito dos direitos, no sentido que não existem restrições de liberdade e oportunidade por motivo de credo, raça ou origem social. Considera-se livre também a concorrência, principalmente em relação à economia, o que garante que o desenvolvimento dos indivíduos ocorra de acordo com o apetite e a capacidade de cada um para atingir os melhores níveis. A economia liberal tem como principal característica o "livre-mercado", proposto por Adam Smith. Isso quer dizer que os produtos têm seus preços fixados pelo produtor que terá a possibilidade de aceitar a resposta do mercado ou desistir da produção. Essa resposta do mercado depende do interesse dos consumidores pelo produto. Se o interesse for grande, os preços serão altos, acarretando em mais pessoas interessadas em produzi-lo. Conforme aumenta a oferta do produto, os preços irão cair, caracterizando o que chamam de "harmonia natural dos interesses".

Segundo Rostow (1978) as sociedades existentes até hoje não atingiram um equilíbrio econômico devido às guerras e às intervenções políticas e econômicas do governo, lembrando Schumpeter (1982) que não é possível explicar a mudança econômica somente pelas condições econômicas prévias e sim pela situação total precedente. Para Schumpeter (1982), o mundo econômico é relativamente autônomo e tende por meio da teoria do fluxo circular a uma situação de equilíbrio econômico que não necessariamente será sempre a mesma, acrescentando que a economia muda de acordo com as mudanças sociais, sofrendo alterações para acompanhar as mudanças sociais. Essas mudanças, portanto, acabam por gerar crescimento econômico, mas não desenvolvimento.

Ao usar o termo desenvolvimento, toma-se como base o conceito de Schumpeter (1982), caracterizado somente por mudanças da vida econômica, que não lhe foram impostas por fatores não econômicos. Ele propõe, portanto, que seja chamado de desenvolvimento econômico as alterações advindas da introdução de um novo bem, de um novo método de produção, da abertura de um novo mercado, de uma nova fonte de oferta de matérias primas e/ou do estabelecimento de uma nova organização de qualquer indústria (SCHUMPETER, 1982, p. 48), que não gerará somente crescimento, mas alteração interna da economia, ou seja, o termo está relacionado com a qualidade da evolução econômica. 
Já o termo crescimento é caracterizado pelo aumento da quantidade produzida. Nesse caso, ao invés de haver a criação de novas tecnologias, por exemplo, haverá o aumento da produção, utilizando as mesmas técnicas, afetando o equilíbrio econômico.

Caso não consiga utilizar os meios de produção que possui, o empreendedor deve recorrer aos créditos, os quais são, de acordo com Schumpeter (1982), a função dos capitalistas. Sendo assim, os Investimentos Estrangeiros Diretos funcionam como esses créditos aos quais o autor se refere, visto que representam a entrada de capital e/ou de equipamentos em um outro país para suprir a demanda deste por meios produtivos.

O Investimento Estrangeiro Direto, portanto, pode ser fonte de desenvolvimento, pois acarreta mudanças no fluxo econômico circular seja pela entrada de capital em alguma indústria já existente ou pela instalação de uma filial no país receptor. De qualquer forma, haverá uma mudança na economia daquele Estado que está recebendo o investimento.

\section{Teoria Dinâmica da Produção}

A Teoria Dinâmica da Produção desenvolvida por W. W. Rostow (1978) vem complementar a teoria clássica da produção à medida que busca isolar a distribuição de renda entre consumo, poupança e investimento, focalizando a composição do investimento e as transformações ocorridas dentro de setores particulares da economia. Torna-se interessante analisar historicamente esses setores, pois eles vão se alternando, dependendo dos fluxos de tecnologia e de investimentos. Portanto, essa teoria será utilizada como forma de identificar as alterações ocorridas dentro dos setores da economia brasileira, advindas dos investimentos estrangeiros.

Infere-se, portanto, que o Investimento Estrangeiro Direto (IED) é uma forma de interferência no mercado de outro país, funcionando como um dos itens do "livre-mercado", influenciando na concorrência desse mercado e alterando assim a "harmonia natural de interesses". 
Os países líderes tanto na emissão quanto no recebimento de IED são os desenvolvidos. De acordo com estimativas feitas em 2007 pela Conferência das Nações Unidas sobre o Comércio e o Desenvolvimento (UNCTAD), o fluxo anual de Investimentos Estrangeiros Diretos na economia global atingiria o recorde de US\$ 1,5 trilhão, US\$ 34,6 bilhões destes direcionados ao Brasil, representando 2,31\% dos investimentos estrangeiros diretos globais (UNCTAD, 2008). Porém, conforme pode ser observado na Tabela 1, essa estimativa foi superada, atingindo US\$ 1,8 trilhão.

Tabela 1 Fluxos de Entrada de IED, 1999-2007 (US\$ bilhões)

\begin{tabular}{|c|c|c|c|c|c|c|c|c|c|}
\hline & $\mathbf{1 9 9 9}$ & $\mathbf{2 0 0 0}$ & $\mathbf{2 0 0 1}$ & $\mathbf{2 0 0 2}$ & $\mathbf{2 0 0 3}$ & $\mathbf{2 0 0 4}$ & $\mathbf{2 0 0 5}$ & $\mathbf{2 0 0 6}$ & $\mathbf{2 0 0 7}$ \\
\hline Mundo & $\mathbf{1 . 0 9 8 , 9}$ & $\mathbf{1 . 4 1 1 , 4}$ & $\mathbf{8 3 2 , 6}$ & $\mathbf{6 2 2 , 0}$ & $\mathbf{5 6 4 , 1}$ & $\mathbf{7 4 2 , 1}$ & $\mathbf{9 4 5 , 8}$ & $\mathbf{1 . 3 0 5 , 8}$ & $\mathbf{1 . 8 8 3 , 3}$ \\
\hline $\begin{array}{c}\text { Variação (\%) } \\
\text { Anual }\end{array}$ & $28,4 \%$ & $41,0 \%$ & $25,3 \%$ & $-9,3 \%$ & $31,6 \%$ & $27,4 \%$ & $38,1 \%$ & $44,2 \%$ \\
\hline $\begin{array}{c}\text { Economias } \\
\text { desenvolvidas }\end{array}$ & $\mathbf{8 6 0 , 1}$ & $\mathbf{1 . 1 4 6 , 2}$ & $\mathbf{6 0 9 , 1}$ & $\mathbf{4 4 2 , 3}$ & $\mathbf{3 6 1 , 2}$ & $\mathbf{4 1 8 , 8}$ & $\mathbf{5 9 0 , 3}$ & $\mathbf{8 5 7 , 5}$ & $\mathbf{1 . 2 4 7 , 6}$ \\
\hline $\begin{array}{c}\text { Participação no } \\
\text { total mundial }\end{array}$ & $78,3 \%$ & $81,2 \%$ & $73,2 \%$ & $71,1 \%$ & $64,0 \%$ & $56,4 \%$ & $62,4 \%$ & $65,7 \%$ & $66,2 \%$ \\
\hline $\begin{array}{c}\text { Economias em } \\
\text { desenvolvimento }\end{array}$ & $\mathbf{2 2 8 , 5}$ & $\mathbf{2 5 6 , 1}$ & $\mathbf{2 1 2 , 0}$ & $\mathbf{1 6 6 , 3}$ & $\mathbf{1 7 8 , 7}$ & $\mathbf{2 8 3 , 0}$ & $\mathbf{3 1 4 , 3}$ & $\mathbf{3 7 9 , 1}$ & $\mathbf{4 9 9 , 7}$ \\
\hline $\begin{array}{c}\text { Participação no } \\
\text { total mundial }\end{array}$ & $20,8 \%$ & $18,1 \%$ & $25,5 \%$ & $26,7 \%$ & $31,7 \%$ & $38,1 \%$ & $33,2 \%$ & $29,0 \%$ & $26,5 \%$ \\
\hline Europa & $\mathbf{5 2 1 , 2}$ & $\mathbf{7 2 1 , 9}$ & $\mathbf{3 9 2 , 7}$ & $\mathbf{3 1 4 , 6}$ & $\mathbf{2 7 7 , 1}$ & $\mathbf{2 0 9 , 2}$ & $\mathbf{4 9 5 , 0}$ & $\mathbf{5 6 6 , 4}$ & $\mathbf{8 4 8 , 5}$ \\
\hline América do Norte & 308,1 & 380,8 & 187,1 & 96,6 & 60,6 & 135,5 & 129,9 & 244,4 & 232,8 \\
\hline África & $\mathbf{1 2 , 4}$ & $\mathbf{9 , 7}$ & $\mathbf{2 0 , 0}$ & $\mathbf{1 3 , 6}$ & $\mathbf{1 8 , 7}$ & $\mathbf{1 8 , 0}$ & $\mathbf{2 9 , 6}$ & $\mathbf{3 5 , 5}$ & $\mathbf{5 3 , 0}$ \\
\hline $\begin{array}{c}\text { América Latina e } \\
\text { Caribe }\end{array}$ & $\mathbf{1 0 4 , 0}$ & 97,8 & $\mathbf{7 8 , 5}$ & 54,3 & 44,7 & 94,3 & 75,5 & 83,7 & 126,3 \\
\hline Ásia e Oceania & $\mathbf{1 1 2 , 0}$ & $\mathbf{1 4 8 , 6}$ & $\mathbf{1 1 3 , 6}$ & $\mathbf{9 8 , 4}$ & $\mathbf{1 1 5 , 3}$ & $\mathbf{1 7 0 , 7}$ & $\mathbf{2 0 9 , 1}$ & $\mathbf{2 5 9 , 8}$ & $\mathbf{3 2 0 , 5}$ \\
\hline
\end{tabular}

Fonte: Elaborado pela autora com base nos indicadores de IED do website FDIStat, da UNCTAD, e na declaração à imprensa "Assessing the impact of the current financial and economic crisis on global FDI flows" de janeiro de 2009 també da UNCTAD

Lembrando que o objetivo do presente trabalho é analisar se a relação entre a evolução qualitativa das economias receptoras e os investimentos estrangeiros diretos é verdadeira, tendo como base os investimentos em diversas áreas da economia brasileira, faz-se necessário registrar que, no Brasil, a aplicação do capital estrangeiro e as remessas de valores para o exterior são disciplinadas pela Lei $\mathrm{n}^{\circ} 4.131 / 62$, modificada pela Lei $\mathrm{n}^{\circ} 4.390 / 64$ e regulamentada pelo Decreto ${ }^{\circ}$ $55.762 / 65$.

Essas leis e o decreto definem os conceitos de capitais estrangeiros, recursos financeiros ou monetários, reinvestimentos e investimentos externos diretos, 
além de detalhar o processo de registro de capital que é obrigatório. É importante ressaltar também que há limitações aos IED. Eles são passíveis de vedações nos casos de serviços na área de saúde, serviços de correios e telégrafos e investimentos relacionados com a indústria aeroespacial ou energia nuclear. E podem sofrer restrições quando tratam de imóveis rurais, imóveis localizados em zonas fronteiriças, instituições financeiras/ seguradoras e meios de comunicação como jornais, revistas, rádio e televisão.

\section{Inserção Internacional do Brasil}

A inserção internacional do Brasil é historicamente ampla e profunda. $\mathrm{O}$ padrão de inserção internacional da economia brasileira foi alterado ao longo do tempo, em função da situação político-econômica em âmbito nacional e da evolução do sistema mundial. Apesar dessas mudanças, o capital internacional sempre teve papel de destaque na história econômica do país, seja na forma de empréstimos, financiamentos, investimentos de portfólio ou investimentos diretos.

Em 1973 e em 1979 ocorreram as famosas crises do Petróleo. Para a economia brasileira um dos efeitos foi a crise da dívida externa que praticamente inviabilizou a entrada de investimentos e por isso a década de 80 ficou conhecida como Década Perdida. O fluxo mundial de IED diminuiu 14,47\% em 1982 e 14,67\% em 1983. Na América Latina, a queda do nível de IED foi mais acentuada, chegando a atingir 26,8\% em relação ao ano anterior, em 1983 . No Brasil, as maiores quedas foram registradas em 1983 e 1986, atingindo $58,1 \%$ e $78,6 \%$, respectivamente, em relação aos anos anteriores. Em 1987, o país registrou um crescimento anual de $300 \%$ em seu influxo de IED, atingindo o valor de 1,2 bilhões de dólares. Apesar do grande aumento em relação ao ano anterior, o influxo de IED não foi grande, tendo sido maior apenas que os influxos de 1986 (USD 0,3 bilhões) e do período anterior a 1975. Ainda assim, nesse mesmo ano, o Brasil veio a declarar moratória dos juros da dívida externa (CARBONELL, 2008, p.15).

No começo da década de 1990, foram adotadas políticas, visando promover a abertura comercial ao exterior. Começou aí a fase das privatizações com o objetivo de suprir a carência nos serviços de infraestrutura. Também nessa época, na 
tentativa de conter a inflação, foi criado com sucesso o Plano Real. Consequentemente, os fluxos de IED aumentaram significativamente a partir de 1994/95 com a estabilização da economia brasileira.

Foi relevante também para o sucesso da política externa brasileira a criação do Mercado Comum do Sul (MERCOSUL) iniciada, em 1991, com o objetivo de reduzir ou eliminar impostos, proibições e restrições entre o comércio dos produtos dos países-membros. Muito se comenta a respeito desse bloco econômico visto que seus países-membros alcançaram, em pouco tempo de existência, um crescimento rápido nos fluxos intrarregionais de comércio e de investimento, sendo avaliados no contexto de economias em desenvolvimento. Houve, com a sua criação, uma busca por maior cooperação e interdependência entre os Estados-membros, sem que o MERCOSUL se tornasse o assunto principal nas agendas dos países. Para o Brasil, pensando em Comércio Exterior, esse bloco permitiu uma maior competitividade à produção local brasileira, visto que o Brasil detém 70\% do PIB do MERCOSUL.

Diante das crises Tequila (México, 1994), Saquê (Japão, 1997) e Russa (1998), os investidores tomaram aversão a riscos e isso prejudicou muito o Brasil que teve que alterar suas políticas monetária, cambial e fiscal. O Brasil, porém, ao invés de desvalorizar sua moeda, decidiu agir de maneira distinta aos outros países no começo das crises e, em janeiro de 2000, liberou o câmbio, permitindo que o mercado regulasse o valor do real. Nesse período, o dólar chegou a R $\$ 4,00$, mas em seguida foi se ajustando, voltando a patamares inferiores, já que o país mostrou estar no caminho certo para controlar sua economia.

No ano 2000, houve um aumento no fluxo mundial de IED, chegando ao patamar recorde de US\$ 1,4 trilhão. O Brasil acompanhou essa tendência, porém a América Latina e o Caribe não tiveram a mesma sorte. Em 2001, houve a Crise Argentina, a queda nas bolsas dos EUA, o desaquecimento da economia global, em decorrência dos atentados terroristas de 11 de setembro e conturbações bélicas, bem como fraudes descobertas na contabilidade de grandes empresas americanas e multinacionais. No Brasil, a crise energética, a diminuição da quantidade de privatizações e a proximidade das eleições presidenciais foram pontos chaves que 
levaram a uma queda maior ainda nos influxos de IED. As eleições presidenciais desse ano apontavam na direção de uma mudança de legenda partidária, na qual um governo de esquerda seria o provável sucessor na presidência do país.

Ao final das eleições de 2002, assumiu a presidência do Brasil o presidente Luiz Inácio Lula da Silva do PT. O partido cumpriu a promessa de manter a política macroeconômica do governo anterior, o que recuperou a confiança dos investidores estrangeiros. Em 2004, os IED recebidos cresceram 79,2\% e, em 2007, atingiram um novo recorde, de US\$37,4 bilhões.

A Tabela 2 demonstra a entrada de IED nos diversos setores da economia para enfim verificar se há ou não relação direta entre a entrada de IED e o desenvolvimento dos setores da economia brasileira. Por meio dela, percebe-se que do ano 2000 até 2003 aconteceram sucessivas diminuições na entrada total de IED, principalmente pela redução na quantidade de empresas passíveis de privatizações, sendo o terceiro setor o responsável pela maior entrada de IED em todos os anos, seguido pelo setor secundário e, por fim, o primário. Após o ano 2003, há aumentos progressivos na entrada total de IED, mantendo o ranking de preferência dos investidores.

Tabela 2 Entrada de IED por setores da economia brasileira (2000 - 2007), US\$ milhões.

\begin{tabular}{|c|c|c|c|c|c|c|c|c|}
\hline Setor & 2000 & 2001 & 2002 & 2003 & 2004 & 2005 & 2006 & 2007 \\
\hline TOTAL & 29876 & 21095 & 18778 & 12902 & 20265 & 21638 & 22706 & 34335 \\
\hline $\begin{array}{c}\text { Agricultura, pecuária e } \\
\text { extrativa mineral }\end{array}$ & 649 & 1500 & 638 & 1482 & 1071 & 2194 & 1542 & 4751 \\
\hline $\begin{array}{c}\text { Extração de minerais } \\
\text { metálicos }\end{array}$ & - & - & 35 & 918 & 507 & 996 & 595 & 3249 \\
\hline $\begin{array}{c}\text { Extração de petróleo e } \\
\text { serviços relacionados }\end{array}$ & 481 & 1360 & 508 & 365 & 285 & 897 & 532 & 892 \\
\hline $\begin{array}{c}\text { Agricultura, pecuária e } \\
\text { serviços relacionados }\end{array}$ & - & - & - & - & 166 & 210 & 176 & 303 \\
\hline Demais & 169 & 140 & 95 & 199 & 112 & 92 & 239 & 307 \\
\hline Indústria & 5087 & 6924 & 7617 & 4480 & 10699 & 6529 & 8462 & 13481 \\
\hline $\begin{array}{c}\text { Fabr. e mont. de veículos } \\
\text { automotores }\end{array}$ & 961 & 1556 & 1819 & 966 & 850 & 1044 & 290 & 861 \\
\hline Produtos químicos & 1118 & 1528 & 1573 & 916 & 1363 & 764 & 936 & 1378 \\
\hline $\begin{array}{c}\text { Produtos alimentícios e } \\
\text { bebidas }\end{array}$ & 975 & 560 & 1873 & 409 & 5346 & 2075 & 525 & 1378 \\
\hline Metalurgia básica & 246 & 428 & 139 & 351 & 817 & 310 & 1713 & 4699 \\
\hline
\end{tabular}




\begin{tabular}{|c|c|c|c|c|c|c|c|c|}
\hline Setor & 2000 & 2001 & 2002 & 2003 & 2004 & 2005 & 2006 & 2007 \\
\hline Máquinas e equipamentos & 579 & 323 & 391 & 256 & 313 & 255 & 357 & 428 \\
\hline $\begin{array}{c}\text { Celulose, papel e produtos } \\
\text { do papel }\end{array}$ & 10 & 148 & 11 & 348 & 177 & 167 & 1619 & 477 \\
\hline $\begin{array}{c}\text { Edição, impressão e } \\
\text { reprodução de gravações }\end{array}$ & 23 & 140 & 44 & 145 & 131 & 26 & - & - \\
\hline $\begin{array}{c}\text { Produtos minerais não- } \\
\text { metálicos }\end{array}$ & 67 & 127 & 124 & 49 & 219 & 17 & 152 & 454 \\
\hline $\begin{array}{c}\text { Máquinas p/ escritório e } \\
\text { equip de informática }\end{array}$ & - & - & 95 & 8 & 11 & 59 & 294 & 159 \\
\hline Produtos de madeira & - & - & 16 & 31 & 61 & 124 & - & - \\
\hline Outras indústrias & 1108 & 2114 & 1532 & 1001 & 1411 & 1688 & 2576 & 3647 \\
\hline Serviços & 24139 & 12671 & 10523 & 6940 & 8495 & 12915 & 12702 & 16103 \\
\hline Correio e telecomunicações & 10897 & 4171 & 4190 & 2810 & 2970 & 3958 & - & - \\
\hline Intermediação financeira & 6384 & 2221 & 1206 & 706 & 940 & 1294 & - & - \\
\hline Comércio & 1635 & 1704 & 1504 & 860 & 1252 & 2835 & 1527 & 2759 \\
\hline $\begin{array}{c}\text { Eletricidade, gás e água } \\
\text { quente }\end{array}$ & 2972 & 1443 & 1534 & 651 & 1191 & 1571 & 2332 & 1055 \\
\hline $\begin{array}{c}\text { Seguros e previdência } \\
\text { privada }\end{array}$ & 14 & 630 & 216 & 128 & 126 & 861 & 252 & 516 \\
\hline Alojamento e alimentação & 0 & 275 & 126 & 172 & 74 & 128 & - & - \\
\hline Construção & 12 & 254 & 148 & 177 & 324 & 203 & 613 & 1240 \\
\hline Atividades imobiliárias & 41 & 188 & 197 & 188 & 145 & 297 & 890 & 822 \\
\hline Transporte & 44 & 146 & 124 & 189 & 252 & 207 & 163 & 387 \\
\hline Outros serviços & 2140 & 1639 & 1278 & 1059 & 1221 & 1561 & 6925 & 9324 \\
\hline
\end{tabular}

Fonte: Elaborado pela autora com base nos Boletins do Banco central do Brasil - Relatórios Anuais (2000 a 2007).

Nota-se que os setores que mais se destacaram na indústria foram o de fabricação e montagem de veículos automotores, a indústria de produtos químicos e a de produtos alimentícios e bebidas apresentando os maiores valores de IED com exceção do ano 2007, cujo destaque foi a indústria de metalurgia básica. Já no setor terciário, os maiores receptores foram os serviços de correios e telecomunicações, de intermediação financeira, de comércio e de eletricidade, de gás e de água quente. No setor primário por sua vez, a agricultura foi o principal receptor de IED.

Faz-se relevante notar que nem sempre os receptores que tiveram aumento maior foram os que tiveram maior montante total de IED no período analisado.

Uma análise conjunta da entrada de IED na economia brasileira e de seu crescimento interno como tentativa de analisar se há uma relação direta entre esses 
dados foi elaborada, utilizando as duas tabelas a seguir. A Tabela 3 representa o total de entrada de IED por setores, enquanto a Tabela 4 mostra o montante anual em valores correntes do PIB nos diferentes setores da economia. A Tabela 4 foi obtida pela divisão dos valores totais em reais pelataxa média anual de câmbio de compra de dólar.

Tabela 3 Valores correntes de entrada de IED no Brasil (US\$ milhões)

\begin{tabular}{|c|c|c|c|c|}
\hline Ano & $\mathbf{1}^{\mathbf{0}}$ Setor & $\mathbf{2}^{\mathbf{0}}$ Setor & $\mathbf{3}^{\mathbf{0}}$ Setor & Total IED \\
\hline 2000 & 649 & 5.087 & 24.139 & 29.875 \\
\hline 2001 & 1.500 & 6.924 & 12.671 & 21.095 \\
\hline 2002 & 638 & 7.617 & 10.523 & 18.778 \\
\hline 2003 & 1.482 & 4.480 & 6.940 & 12.902 \\
\hline 2004 & 1.071 & 10.699 & 8.495 & 20.265 \\
\hline 2005 & 2.194 & 6.529 & 12.915 & 21.638 \\
\hline 2006 & 1.542 & 8.462 & 12.701 & 22.705 \\
\hline 2007 & 4.751 & 13.481 & 16.103 & 34.335 \\
\hline
\end{tabular}

Fonte: Elaborado pela autora com base em dados dos Boletins do Banco Central do Brasil Relatórios Anuais (2000 a 2007).

Tabela 4 Valores correntes do PIB na economia brasileira (US\$ milhões)

\begin{tabular}{|c|c|c|c|c|c|c|}
\hline Ano & Agropecuária & Indústria & Serviços & Outros & PIB & $\begin{array}{c}\text { Variação } \\
\text { Percentual } \\
\text { Real }\end{array}$ \\
\hline 2000 & 31.289 & 154.871 & 372.300 & 86.276 & 644.737 & \\
\hline 2001 & 28.438 & 128.180 & 319.468 & 78.108 & 554.195 & 1,3 \\
\hline 2002 & 28.849 & 117.931 & 289.163 & 70.091 & 506.034 & 2,7 \\
\hline 2003 & 35.295 & 133.064 & 309.502 & 74.520 & 552.380 & 1,1 \\
\hline 2004 & 39.381 & 171.540 & 358.720 & 94.096 & 663.737 & 5,7 \\
\hline 2005 & 43.199 & 221.526 & 492.034 & 125.282 & 882.040 & 3,2 \\
\hline 2006 & 51.133 & 269.205 & 615.043 & 154.031 & 1.089 .412 & 4,0 \\
\hline 2007 & 68.314 & 320.333 & 753.317 & 192.128 & 1.334 .092 & 5,7 \\
\hline 2008 & 89.164 & 372.115 & 869.648 & 244.624 & 1.575 .551 & 5,1 \\
\hline
\end{tabular}

Fonte: Elaborado pela autora com base em dados do IBGE, Diretoria de Pesquisas, Coordenação de Contas Nacionais e Ipeadata.

À primeira vista, nota-se que enquanto as entradas de IED não são constantes, ou seja, às vezes aumentam e às vezes decrescem, o crescimento da economia 
nacional, ou melhor, o crescimento do PIB nacional é marcado por sucessivos aumentos. Isso se repete em todas as colunas, por exemplo, enquanto no ano 2002 há uma redução no $1^{\circ}$ setor de US\$1.500 milhões para US\$ 638 milhões, na entrada de IED, há um aumento de US\$28.438 milhões para US\$ 28.849 milhões. Outro exemplo é na passagem de 2002 para 2003: o total de IED no último ano é igual a $68,71 \%$ do total do primeiro ano, enquanto isso o crescimento do PIB de $2004 \mathrm{em}$ relação a 2003 é de 5,7\%.

Uma explicação possível para essa divergência é que os IED são atraídos pela estabilidade política e econômica do país receptor. De acordo com Kotler em seu livro O Marketing das Nações (KOTLER; JATUSRIPITAK; MAESINCEE, 1997, p. 181) o temor consiste nas consequências das decisões políticas referentes à transferência de recursos ao exterior ou à pressão para que haja nacionalizações. Tomando por base esse viés, nota-se relação entre a teoria e a realidade visto que os períodos de queda na entrada de IED foram marcados pela transição de governo, ou melhor, especificando, entre os anos 2001 e 2003.

A falta de estabilidade econômica acarreta no temor de recessões econômicas, depreciação da moeda e greves entre outros, sendo expressa normalmente pelo Risco-país. O Risco-país é um índice denominado Emerging Markets Bond Index Plus (EMBI+) e mede o grau de "perigo" que um país, normalmente emergente, representa para o investidor estrangeiro. Tecnicamente falando, o risco-país é a sobretaxa que se paga em relação à rentabilidade garantida pelos bônus do Tesouro dos Estados Unidos, país considerado o mais solvente do mundo, ou seja, o de menor risco para um aplicador não receber o dinheiro investido acrescido dos juros prometidos. Quanto maior for o risco, menor será a capacidade do país de atrair investimentos estrangeiros.

Outro fator de atração de IED é a busca por recursos naturais. Levando em consideração que em 2001 houve a crise energética brasileira que ficou conhecida como Crise do Apagão, esse fator também ficou prejudicado nesse período, influenciando negativamente a entrada de IED. Porém ${ }_{2}$ sem crise relacionada a recursos naturais e, aproveitando o bônus de Carbono no Mercado de Carbono brasileiro, os IED voltaram a crescer. 
Mais um fator de atração de IED é a disponibilidade de informações. Nesse sentido o Brasil busca oferecer o máximo de informações possíveis aos investidores estrangeiros por meio de publicações do Ministério das Relações Exteriores (MRE), Ministério do Desenvolvimento Indústria e Comércio (MDIC) entre outros.

Por fim, o acesso a mercados, tanto interno quanto regional, também exerce forte influencia na entrada de IED e esse fator é o que o Brasil possui de melhor. Seu mercado consumidor interno já é expressivo e sua capacidade de crescimento é, geralmente, verificada por meio das taxas de crescimento do país, dos índices de produtividade, das taxas de inflação e seu controle e do equilíbrio fiscal. Visto que, as taxas de crescimento brasileiras têm sido superavitárias e as taxas de inflação têm atingido as metas do Copom ${ }^{2}$, o potencial de crescimento também favorece a entrada de IED.

A respeito do mercado regional em que o Brasil participa ativamente, é relevante o MERCOSUL que possui em sua agenda, entre outros objetivos, a Tarifa Externa Comum (TEC), que consiste em uma tentativa de equalizar as condições de concorrência e garantir que haja integração produtiva entre suas economias. Ou seja, procura ampliar cada vez mais o mercado, a criação de comércio segundo Balassa, visto que proporcionará o aumento da produção interna dos países-membros, de acordo com a teoria das vantagens comparativas de Ricardo; portanto, poderá exportar e importar com mais facilidade e melhores condições de concorrência que outros países.

Portanto, existe relação entre a entrada de IED e o crescimento da economia, verificando que o crescimento da economia nacional atrai IED, pois ele reflete a capacidade de incremento do mercado interno, consistindo em fator relevante para o investidor estrangeiro.

2 Copom é o Conselho de Políticas Monetárias do Banco Central que visa estabelecer metas para controle da inflação. É uma ação pioneira do Bacen e tem servido de modelo para bancos centrais em todo o mundo. 


\section{Conclusão}

Os efeitos do IED como fator de desenvolvimento na economia brasileira não pôde ser comprovado, visto que não exerce significativa alteração no fluxo circular da vida econômica local. Pode-se pensar na economia interna influenciando na entrada de IED, porém o contrário não foi observado na mesma intensidade.

Pôde-se perceber com esse trabalho que o crescimento dos setores da economia nacional reflete a capacidade de crescimento de mercado interno e com isso os investidores estrangeiros têm mais interesse em entrar na economia do país. E que o que propicia o crescimento da economia brasileira é ainda sua Balança Comercial, seu controle de inflação, a criação de novos empregos, a quantidade de consumo das famílias brasileiras e o incremento da produção de acordo com a demanda interna, ou seja, a condução do setor produtivo e do setor financeiro nacional.

Outra conclusão importante que pôde ser observada com base nas pesquisas para este trabalho refere-se à comprovação da teoria de Schumpeter, que demonstra que as mudanças sociais interferem somente no crescimento e não no desenvolvimento da economia. Isso se explica uma vez que acontecimentos não necessariamente ligados diretamente à economia mundial tiveram influências importantes no comportamento econômico, como por exemplo, os atentados terroristas às Torres Gêmeas em 11 de setembro de 2001, a instauração de Comissões Parlamentares de Inquérito no Brasil e as eleições brasileiras que são fatores mais políticos que econômicos, mas que interferiram no saldo de IED em todo o mundo, mas não incluiu novos fatores econômicos na economia mundial.

Mais um fator de relevância ao final desta pesquisa é a existência de mitos com relação à atração de IED no Brasil. O primeiro mito é que o setor mais atrativo da economia brasileira é o primário, referente à agricultura, à pecuária e à extração mineral. A desmistificação se deve à observação de que o setor que recebe maior montante de IED é o de serviços (setor terciário), seguido pelo de indústrias (segundo setor) e somente em último lugar o setor primário.

Outra desmistificação sobre a atração de IED é com relação aos investimentos em infraestrutura, que muitas vezes também são apontados como mais 
atrativos para IED. Porém, os serviços de transporte e construção, por exemplo, são as atividades que recebem menores investimentos no setor de serviços. Ainda pode-se observar que a indústria de produtos alimentícios e bebidas é a que sofre maiores aumentos percentuais de entrada de IED.

Esses mitos, no entanto, acontecem devido à importância desses setores na economia nacional. O país contém em sua economia importantes empresas responsáveis pelas áreas de infraestrutura como as de transporte, a metalurgia e a agricultura que exercem importante papel nas exportações brasileiras.

Observou-se também que a economia brasileira vem apresentando crescimentos sucessivos e isso tem refletido positivamente na entrada de IED que, desde 2003, acompanha essa tendência. Porém não se pode deixar de mencionar a crise econômica iniciada no meio de 2007 que fez crescer a esfera de incertezas e preocupações sobre as perspectivas globais de investimento. Isto é, embora o governo brasileiro tenha afirmado no começo da crise que os efeitos não chegariam tão devastadores ao Brasil, esse ritmo de crescimento da economia nacional deverá diminuir consideravelmente, impactando também nos influxos de IED. Dados do ano de 2008 não haviam sido divulgados antes da conclusão dessa pesquisa, consequentemente não pudemos colocar dados da crise, mas não podemos afirmar se ela deixará consequências na entrada de IED no Brasil.

Dados sobre onde estão ocorrendo os IED do Brasil no exterior e quais são os motivadores para o Brasil investir no exterior foram levantados de forma rápida neste trabalho, porém há a consciência da importância dessa vertente de IED, que deverá ser explorada em trabalhos futuros.

Portanto, percebe-se que o Brasil possui diversas características favoráveis ao seu crescimento e que elas têm sido muito bem aproveitadas pelos investidores nacionais, demonstrando que a economia nacional é menos dependente do que era esperado observar neste trabalho.

Contudo, o governo nacional deveria investir mais em resolver as deficiências estruturais, ampliando assim os ganhos nacionais, ou melhor dizendo, aumentando 
o crescimento nacional e atraindo maiores IED, que apesar de não desempenharem papel tão relevante na economia nacional, ampliam as oportunidades de comércio internacional do país, abrem portas para maior entrada de inovações tecnológicas e aumentam as reservas internacionais brasileiras.

\section{Influence of foreign direct investment in brazilian economy: an analyze by economy's sectors}

\section{Abstract}

The major purpose of this paper is to analyze the influence of Foreign Direct Investments (FDI) entrance in the several Brazilian economies' sectors. In order to this, it was observed the global flow of FDI, the Brazilian legislation that regulates the FDI's entrance, such as the historical context that has influenced the FDI's inflows in Brazil. Then it was analyzed the entrance of FDI and the growth of Brazilian's Economy sectors, between year 2000 and 2008, observing if there is a direct relations between them. Finally, contends that the two analyzed factors are connected, but the national economy's growth influences more in the entrance of FDI then the opposite, and also are shown others factors that influences the FDI entrance and the intern growth, suggesting more national investments in order to attract more FDI to enlarge the international commerce and obtain more technology development.

Keywords: Foreign Direct Investment's. Economies sectors. Growth, development

\section{Referências}

BANCO CENTRAL DO BRASIL.. Risco país. Disponível em: <http://www4.bcb. gov.br/pec/gci/port/focus/FAQ09-Risco-Pa\%C3\%ADs.pdf >. Acesso em: 14 maio 2009. (Série Perguntas mais freqüentes).

BANCO CENTRAL DO BRASIL. O boletim do banco central do Brasil: relatórios 2000 a 2007. Disponível em: <http://www.bcb.gov.br/?RED-BOLETIMANO>. Acesso em: 14 nov. 2008. 
BARROS, Octavio de; GIAMBIAGI, Fábio. Brasil globalizado: o Brasil em um mundo surpreendente. Rio de Janeiro:Campus, 2008.

BOVESPA. Guia prático bovespa para investimentos estrangeiros de portfólio. Disponível em: <http://www.bovespa.com.br/pdf/guiaportfolio. pdf> Acesso em: 17 jan. 2009.

BRASIL. Lei n. 4.131, de 3 de setembro de 1962. Disciplina a aplicação do capital estrangeiro e as remessas de valores para o exterior e dá outras providências. Disponível em: < http://www.planalto.gov.br/CCIVIL/LEIS/ L4131.htm >. Acesso em: 20 nov. 2008.

BRASIL. Lei n. 4.390, de 29 de agosto de 1964. Altera a Lei no 4.131, de 3 de setembro de 1962, e dá outras providências. Disponível em: <http://www.planalto.gov.br/ ccivil_03/Leis/L4390.htm > Acesso em 10 fev. 2008

CARBONELL, Lívia Machado. Fluxos mundiais de investimento estrangeiro direto e participação do Brasil como receptor desses investimentos. Monografia de Graduação defendida no curso de Relações Internacionais do UNICEUB. Brasília, 2008.

FERNANDO FILHO, Paulo de Mello Barreto. O tratamento nacional de investimentos estrangeiros. Brasília: Instituto Rio Branco, 1999.

GONÇALVES, Reinaldo. Globalizacion productiva, inversión externa directa y empresas transnacionales em el Brasil: uma prespectiva histórica globalizacion productiva, inversion. Disponível em: <http://bibliotecavirtual. clacso.org.ar/ar/ libros/unesco/gonca.rtf >. Acesso em: fev 2009.

GREGORY, Denise; OLIVEIRA, Maria Fátima Berardinelli Anaes de. $O$ desenvolvimento de ambiente favorável no Brasil para a atração de IED. Disponível em: <http:/apache.camara.gov.br/portal/arquivos/Camara/inter net/comissoes/ credn/publicacao/Artigo\%20IED\%20010705.pdf > . Acesso em: fev. 2009.

GUIA legal para o investidor estrangeiro no Brasil = Legal guide for the foreign investor in Brazil. [8. ed.]. Brasília: Ministério das Relações Exteriores: São Paulo: CESA, 2006.

KOTLER, Philip; JATUSRIPITAK, Somkid; MAESINCEE, Suvit. O marketing das nações: uma abordagem estratégica para construir as riquezas nacionais. São Paulo: Futura, 1997.

ROSTOW, W. W. Etapas do desenvolvimento econômico. 6. ed. Rio de Janeiro: Zahar, 1978. 
SCHUMPETER, Joseph Alois. Teoria do desenvolvimento econômico: uma investigação sobre lucros, capital, crédito, juro e o ciclo econômico. São Paulo: Abril Cultural, 1982.

SILVA, Luis Inácio Lula da. Carta ao povo. Disponível em: <http://www.iisg.nl/ collections/carta_ao_povo_brasileiro.pdf>. Acesso em: 09 fev. 2009.

SOARES, Cláudio César Soares. Introdução ao comércio exterior: fundamentos teóricos do comércio internacional. São Paulo: Saraiva, 2004.

UNCTAD HANDBOOK of Statistics 2008. Disponível em <http://www. unctad. org/en/docs/tdstat33_en.pdf> Acesso em: 21 out. 2008.

UNITED NATIONS. United nations conference on trade and development World investment prospects survey: 2008: 2010. Disponível em: < http://www.unctad.org/ en/docs/wips2008_en.pdf>. Acesso em: 03 nov. 2008.

UNITED NATIONS. United nations conference on trade and developmente World Investment Report 2008: transnational corporations and the infrastructure challenge. Disponível em: <http://www.unctad.org/en/docs/ wir2008_en.pdf >. Acesso em: 21 out. 2008. 
